\title{
RESENHA - UMA OBRA QUE GANHOU MAIORIDADE
}

Fábio Guedes Gomes

Em 2015 chegou às mãos e desfrute da sociedade alagoana e nordestina um livro essencial para a compreensão da evolução histórica, geográfica, social, econômica e política de Alagoas. Não obstante o título ser Formação Histórica de Alagoas, o livro do professor da Universidade Federal de Alagoas, Cícero Péricles de Carvalho, lançado pela Edufal, passeia por aquelas áreas amarrando temas essenciais que não podem ser negligenciados quando o que verdadeiramente importa é a compreensão das raízes de um tipo tão singular de construção societal.

Apesar de ser a $3^{\text {a }}$ edição, é um livro completamente novo, porque as duas primeiras foram disponibilizadas no ano de 1980. Esse intervalo de 35 anos tornou o atual texto muito mais desenvolvido, com a inclusão de novos capítulos cobrindo esse longo período. Foram superadas algumas imprecisões, revisada a forma de exposição e incluída uma elegante e moderna apresentação visual.

Quando foi escrito pela primeira vez o prof. Péricles alcançava pouco mais de vinte anos de idade, um ousado e principiante sociólogo. O livro, portanto, carrega em si o amadurecimento de um autor com forte jovialidade laboral e grande preocupação intelectual em continuar contribuindo para a formação da cidadania de seu povo, seu estado. Agora, o sociólogo se mistura ao economista e um atuante militante das causas populares em Alagoas, com experiência suficiente para narrar o passado recente e, principalmente, o que viveu intensamente nessas três décadas e meia que se passaram entre as primeiras versões do livro e a definitiva.

Formação Econômica de Alagoas (a partir daqui FHA) se estrutura seguindo os mesmos passos de clássicos da interpretação brasileira, iniciando pela ocupação territorial e exploração econômica determinadas pela colonização ibérica. Foi assim com Celso Furtado em dois de seus importantes livros, Formação Econômica do Brasil e Economia Latino Americana, e Caio Prado Jr., em Formação do Brasil Contemporâneo. Todos lançados pela prestigiada editora Companhia das Letras em 2007 e 2011, respectivamente

Na primeira parte de FHA, dois séculos são descritos e analisados em 7 capítulos muito bem distribuídos e didaticamente apresentados. Aliás, essa é uma das maiores virtudes da obra. Ela preenche uma enorme lacuna de textos básicos, de fácil compreensão e que possa ser adotado em escolas de ensino fundamental, principalmente numa região do país com índices tão escandalosos de analfabetismo. Nesse caso, o autor demonstrou grande preocupação em organizar 
e escrever o texto numa linguagem o mais acessível possível, entretanto sem perder a qualidade no conteúdo e o perfil crítico de quem realmente se preocupa em atingir a essência explicativa.

Além da primeira parte já referida, o livro se divide em mais quatro: a Comarca (17061817); Capitania e Província (1817-1889); República (a velha; 1889-1930); e, República (a nova; 1930-2012). São mais onze capítulos que abordam três séculos de Nordeste e parte do seu coração territorial que se tornou Alagoas.

Evidentemente que não me debrucei na leitura de FHA nesse pouco tempo. Fui agraciado e honrado pelo autor que disponibilizou a versão em desenvolvimento para uma leitura crítica. Minha curiosidade no material foi tamanha que, em pouco tempo, cumpri a tarefa que me foi dada; os pequenos problemas e algumas lacunas interpretativas não significaram nenhum empecilho. Na versão ainda primária percebi que estava diante de um grande texto.

A começar pela bibliografia, acredito que o prof. Péricles esgotou toda a literatura existente que, de uma forma direta e indireta, trata da questão alagoana. Isso já demonstrava a envergadura do projeto reinventado pelo autor.

Da época em que realizei aquela leitura até a versão agora lançada, se passaram em torno de dois anos. Nesse tempo, o autor não descuidou um minuto de seu projeto, mesmo quando a vida lhe tentou pregar uma peça. Aguardou pacientemente o momento ideal para que seu livro ganhasse o mundo. "Lambeu a cria", como se diz comumente, até o filho intelectual ficar preparado à crítica em geral.

E nessa linha, mesmo compreendendo que o autor evitou uma obra meramente acadêmica e mais densa, pouco compreensível ao cidadão comum, considero ainda a necessidade de uma apresentação e introdução. Não acho que esses elementos tornariam o livro mais "pesado", pelo contrário contextualizaria o leitor, o familiarizaria com o conhecimento que iria encontrar pela frente. Mas esse aspecto não diminui, em hipótese alguma, a contribuição do seu conteúdo. Ele é mais um sintoma da humildade intelectual do prof. Péricles do que uma falha, algo que escapou de suas preocupações.

Por fim, não gostaria de fechar essa breve e simplória resenha sem mencionar o que significa FHA para seu próprio autor. Quem o conhece bem e acompanha sua trajetória na Universidade Federal de Alagoas, no curso de economia, e também fora da Instituição, reconhece sua modéstia e a mínima inclinação para o autoelogio. No entanto, o lançamento desse livro inscreve, definitivamente, o professor Cícero Péricles entre os grandes autores alagoanos e uma das principais lideranças e referências intelectuais e acadêmicas no campo das ciências sociais e humanas. 
Formação Histórica de Alagoas e os demais livros já lançados pelo autor, com destaque para Economia Popular: uma via de modernização para Alagoas (6 ${ }^{a}$ Edição, Edufal, 2014), formam um conjunto reflexivo que há muito tem servido à gerações e gerações de estudantes e estudiosos das questões nordestinas e alagoanas, especialmente no campo da economia heterodoxa, ou seja, sem matizes matematizadas ou extremamente formalizadas, distantes em geral dos problemas reais do homem comum.

Formação Histórica de Alagoas chegou em boa hora, alcançou maioridade e, certamente, terá vida longa, ultrapassando os limites do tempo. 